Annals of Tropical Research 32[1]:72-91(2010)

(c) VSU, Leyte, Philippines

\title{
Nitrogen mineralization and phosphorus solubilization due to rewetting of forest and paddy soils
}

\author{
Marco Rodel J. Aragon and Victor B. Asio \\ Department of Agronomy and Soil Science, Visayas State University, \\ Baybay, Leyte, 6521-A Philippines
}

\begin{abstract}
Rewetting of soils may cause an increase in phosphorus solubilization and nitrogen mineralization resulting in the release of bioavailable phosphates and nitrates which are vital for crop growth but are also associated with eutrophication of surface waters. The study was conducted to evaluate $\mathrm{P}$ solubilization and $\mathrm{N}$ mineralization due to drying and rewetting of forest and paddy soils under laboratory conditions. Forest and paddy soils were tested for water extractable $\mathrm{P}$ and mineralizable $\mathrm{N}_{\left(\mathrm{NH}_{4}{ }^{+} \text {and }\right.}$ $\mathrm{NO}_{3}^{-}$) after being subjected to drying and rewetting cycles for 7 and 14 days of drying. Soil samples were also analyzed for $\mathrm{pH}, \mathrm{OM}$, total $\mathrm{N}$, total $\mathrm{P}$, available $\mathrm{P}$, and clay contents. Results indicated a significant increase in water-extractable $\mathrm{P}$ and total mineralized $\mathrm{N}$ for all the samples tested. $\mathrm{N}$ mineralization and $\mathrm{P}$ solubilization were correlated with $\mathrm{OM}$, total $\mathrm{N}$, available $\mathrm{P}$, and clay. Findings also revealed that $\mathrm{NH}_{4}^{+}$ concentration increased while that of $\mathrm{NO}_{3}^{-}$decreased significantly for all the samples tested. The amounts of water-extractable $\mathrm{P}^{-}$and $\mathrm{NO}_{3}^{-}$released due to rewetting could potentially accelerate eutrophication if transported to bodies of water. They could also however benefit the growing plant.
\end{abstract}

Key words: soil rewetting, nitrogen mineralization, phosphorus solubilization, eutrophication

Correspondence: M. R. Aragon Address: Department of Agronomy and Soil Science, Visayas State University, Baybay Leyte 6521-A, Philippines. E-mail: maragon1221@gmail.com

DOI: $10.32945 /$ atr3215.2010 


\section{INTRODUCTION}

Nitrogen and phosphorus are the most limiting essential elements for the existence of life. Thus, their availability in the soil is crucial for biological processes in terrestrial ecosystems such as forest and agricultural ecosystems. Wardle et al. (2004) reported that while nitrogen is biologically renewable, phosphorus is not. Consequently, phosphorus becomes depleted or fixed in the soil and becomes the limiting nutrient over time. In recent decades, however, human activities particularly the use of agricultural inputs like fertilizers and the unregulated disposal of wastes have caused contamination of surface and ground waters with nitrate and phosphate (e.g. Brady and Weil, 2002). Schlesinger (1991) reported that through the production of fertilizers, the rate at which nitrogen and phosphorus enter the biogeochemical cycle has probably doubled. Nitrogen pollution is considered the third major threat to our planet after biodiversity loss and global change (Hubbard Brook Research Foundation, 2003).

In the soil, about 95-99 percent of nitrogen is found in organic compounds, which are not readily available to plants. Microbial decomposition is needed to release ammonium and nitrate ions, the forms absorbed by plants. Because of its negative charge, nitrate is highly mobile in the soil and the environment and much is lost through leaching and ends up in water bodies (Brady and Weil, 2002). Phosphorus in the soil, on the other hand, largely occurs as inorganic compounds, which are generally immobile (Rosen and Horgan, 2006). Under normal soil conditions, leaching losses of inorganic phosphorus are generally low but may still be sufficient to stimulate eutrophication of surface waters (Brady and Weil, 2002; Schachtschabel et al., 1992). This may be considerably increased in areas where phosphate fertilizers are regularly applied.

One particular aspect of nitrate and phosphate dynamics in the soil that remains poorly understood until now concerns the role of rewetting of soils due to normal rainfall fluctuation or due to cultural practices such as irrigation and drainage in paddy soils. Recent studies have revealed that considerable amount of organic phosphorus is released from soil microbial biomass which could contribute to pollution of water bodies when soils are subjected to cycles of drying and rewetting (Turner and Haygarth, 2001; Turner et al., 2003). These authors hypothesized that this may also be applicable to the mineralization 
of nitrogen and other nutrients in the soil. Moreover, its effect on water quality may be increased by irrigation practices and in regions where climate change cause longer dry periods or more frequent cycles of wetting and drying (Houghton et al., 1992). These findings may suggest that the natural release of nitrogen and phosphorus due to drying and rewetting provides the plant with continuous supply of these nutrients in both forest and agricultural ecosystems. However, it may also be an important contributor to the eutrophication of water bodies and the contamination of groundwater systems utilized as source of drinking water. The study evaluated the effects of drying and rewetting of a forest soil and a paddy (rice) soil on $\mathrm{P}$ solubilization and $\mathrm{N}$ mineralization under laboratory conditions. We also wanted to find out if the increase in soluble phosphorus obtained in temperate grassland soils (Turner and Haygarth, 2001) is true for the humid tropical forest and paddy soils of Leyte.

\section{MATERIALS AND METHODS}

\section{Collection and preparation of soil samples}

The study used two typical forest and paddy (rice) soils in Baybay, Leyte, Philippines. One was the forest soil in the rain forest of Mt. Pangasugan and the other was the paddy soil in the adjacent alluvial plain which is intensively used for irrigated lowland rice production. The forest soil was developed from basaltic and andesitic volcanic rocks (Asio, 1996; Navarrete et al., 2009), is strongly weathered, clayey and classified as Ultisol according to Soil Taxonomy (Soil Survey Staff, 2006) or Acrisol in the World Reference Base (IUSS Working Group WRB, 2006). The paddy soil developed from Quaternary alluvial sediments of volcanic origin, is moderately weathered, clay loam and classified as Inceptisol or Gleysol.

Ten bulk soil samples were collected from the A horizon $(0-20 \mathrm{~cm})$ of each soil type making a total of 20 samples. Each of the bulk samples from each site was divided equally into two parts. The first part was air-dried, homogenized, sieved through a $2 \mathrm{~mm}$ mesh sieve and stored in labeled plastic bags for analysis of clay, total $\mathrm{N}$, total $\mathrm{P}$, extractable $\mathrm{P}$, organic matter, and 
$\mathrm{pH}$. The second part was subjected to the drying and wetting procedure and tested for water-soluble $\mathrm{P}$ and mineralizable $\mathrm{N}$.

\section{Drying and rewetting procedure}

The rewetting procedure was done according to Turner and Haygarth (2001) as follows: soil samples were initially saturated and drained for 48 hours in order to attain field capacity. In testing for water soluble P, a subsample at field capacity was extracted with water at 1:4 soil/water ratio for 5 minutes. Another subsample was taken for testing mineralizable $\mathrm{N}$ using $1 \mathrm{~N} \mathrm{KCl}$ as described by Bremner (1965). At 7 and 14 days after the initial extraction, subsamples were again tested for water-soluble $\mathrm{P}$ and mineralizable $\mathrm{N}$ using the same procedure. The data gathered after 7 and 14 days represent the $P$ and $\mathrm{N}$ concentrations that correspond to the rewetting effect of dried soils.

\section{Soil physical and chemical analyses}

Soil $\mathrm{pH}$ was analyzed potentiometrically using a 1:2.5 soil/water ratio (ISRIC, 1995), organic matter (OM) by the Walkley-Black wet oxidation method according to Nelson and Sommers (1982), total N by the Kjeldahl method of Bremner and Mulvaney (1982), mineralizable $\mathrm{N}$ by extraction with $1 \mathrm{~N} \mathrm{KCl}$ as described by Bremner (1965), extractable P using the Olsen method of Olsen and Sommers (1982), water-soluble P by extraction with deionized water at 1:4 soil/solution ratio as described by Turner and Haygarth (2001) and quantified using the method of Murphy and Riley (1962) for color development with ammonium molybdate, total $\mathrm{P}$ using the alkaline oxidation method (Dick and Tabatabai, 1977), and percent clay distribution of the soil samples by pipette method (ISRIC, 1995).

\section{Statistical analysis}

ANOVA was used to detect differences in water-soluble $\mathrm{P}$ and mineralizable $\mathrm{N}$ between days of drying and rewetting. The effect of $\mathrm{pH}$, total $\mathrm{N}$, OM, total $\mathrm{P}$, extractable $\mathrm{P}$ and clay content on $\mathrm{P}$ solubilization and $\mathrm{N}$ mineralization was also tested. Correlation coefficient analysis was done to predict relationships between independent variables $\mathrm{pH}$, total $\mathrm{N}, \mathrm{OM}$, total $\mathrm{P}$, extractable $\mathrm{P}$ and clay content and dependent variable $\mathrm{P}$ solubilization. 
Table 1. Selected chemical and physical properties of the soils used in the study

\begin{tabular}{lclrl}
\hline Soil property & \multicolumn{2}{c}{ Forest soil $(n=10)$} & \multicolumn{3}{c}{ Paddy soil $(n=10)$} \\
\hline $\mathrm{pH}$ (H2O) & 5.51 & \pm 0.11 & 5.34 & \pm 0.06 \\
Clay (\%) & $54.19^{*}$ & \pm 1.97 & 29.73 & \pm 0.93 \\
OM(\%) & $8.67^{* *}$ & \pm 0.62 & 5.21 & \pm 0.16 \\
Total N(\%) & $0.45^{* *}$ & \pm 0.03 & 0.31 & \pm 0.01 \\
Total P (ppm) & 35.22 & \pm 2.44 & 38.48 & \pm 1.61 \\
Extractable P (ppm) & 3.81 & \pm 0.27 & $7.52^{* *}$ & \pm 0.08 \\
\hline
\end{tabular}

* significant using t-test for equality of means (at $5 \%$ level of significance)

$* *$ highly significant using t-test for equality of means (at $1 \%$ level of significance)

$\pm=$ standard error of the mean

\section{RESULTS AND DISCUSSION}

\section{Characteristics of soils}

Table 1 shows the selected chemical and physical properties of the forest and paddy soils used in the study. The soils had $\mathrm{pH}$ values of 5.5 or below indicating that they were strongly acidic (Landon, 1991). Under this chemical soil condition, phosphate solubility is largely controlled by fixation by hydrous oxides of Fe and $\mathrm{Al}$ (Tan, 1993). Nitrogen mineralization is also generally low since the activity of nitrifying bacteria is reduced by the acidic condition. Forest soil was clayey and had higher clay content than the paddy soil. Both soils had moderate amounts of $\mathrm{OM}$ and total $\mathrm{N}$ with the forest soil having significantly $(P<0.01)$ higher amount compared to the paddy soil. Although the soils had comparable amount of total phosphorus, the paddy soil had higher $(P<0.01)$ amount of extractable phosphorus than the forest soil.

\section{Phosphorus solubilization}

Significant increase in water-extractable $P$ across rewetting times attributed to the rewetting effect of dried soils was observed for both forest and paddy soils (Figure 1). Correlation analysis showed that the amount of P solubilized was significantly correlated to $\mathrm{pH}$, total $\mathrm{N}, \mathrm{OM}$ and clay content $(P<0.05)$ 


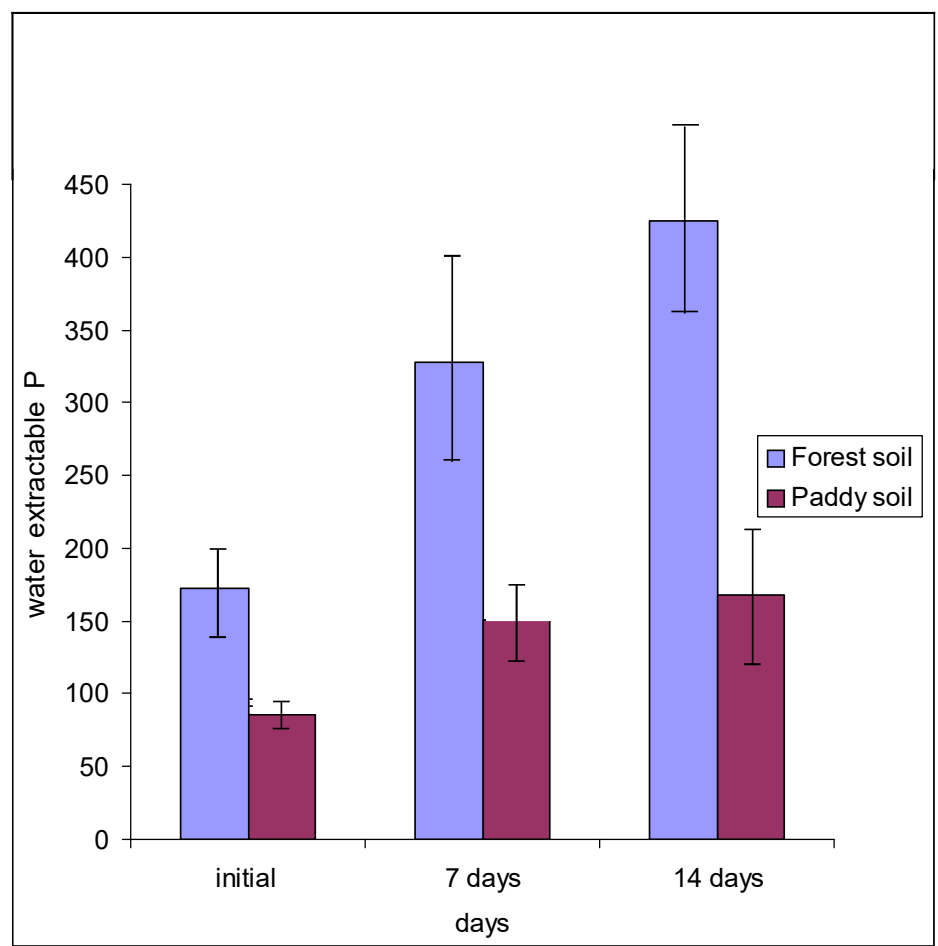

Figure 1. Mean water extractable P concentration of forest and paddy soils at different rewetting times. 
Table 2. Correlation coefficient analysis ( $\mathrm{r}$ ) of $\mathrm{pH}, \mathrm{OM}$, total $\mathrm{N}$, total $\mathrm{P}$, extractable $\mathrm{P}$, clay content relative to total amount of $\mathrm{P}$ solubilized and $\mathrm{N}$ mineralized

\begin{tabular}{llllllll}
\hline & $\mathrm{pH}$ & Clay & OM & Total N & Total P & $\begin{array}{l}\text { Extractable } \\
\mathrm{P}\end{array}$ & $\begin{array}{l}\% \mathrm{~N} \\
\text { mineralized }\end{array}$ \\
\hline & & & & & & & \\
P solubilized & $0.53^{*}$ & $\mathbf{0 . 6 2 *}$ & $0.50^{*}$ & $0.52^{*}$ & -0.33 & -0.43 & $\mathbf{0 . 5 6 *}$ \\
N mineralized & 0.27 & $-0.72^{* *}$ & $0.67^{* *}$ & $\mathbf{0 . 6 0}$ & -0.40 & $-0.72^{* *}$ & 1 \\
\hline
\end{tabular}

* - significant at $5 \%$ level of significance

** - significant at $1 \%$ level of significance

(Table 2). Regression analysis also showed significant $(P<0.05)$ linear relationship of the amount of $\mathrm{P}$ solubilized to $\mathrm{pH}$ and $\mathrm{OM}$ and highly significant $(P<0.05)$ relationship to clay content (Figure 2). Organic matter is related to $P$ solubilization since it contains $\mathrm{P}$ (Sanchez, 1976). The contribution of OM to the amount of $\mathrm{P}$ in the soil solution has also been reported by Guppy et al. (2005) who pointed out that increase in P in the soil solution can result from $\mathrm{OM}$ interactions with $\mathrm{P}$ sorption sites resulting in more $\mathrm{P}$ released into the soil solution. In addition, a potentially more important process is the disruption of OM coatings on clay and mineral surfaces by the physical stresses induced during soil drying. This disruption increases organic matter solubility and exposes formerly protected mineral surfaces (Simonsson et al., 1999). This also partly explains why regression analysis yielded a significant linear relationship of $\mathrm{P}$ solubilization to clay content and $\mathrm{OM}$ for both soils. The response to rewetting includes improved $\mathrm{C}$ availability from decayed microbial biomass and increased availability of soil organic $\mathrm{C}$ (SOC) due to increased exposure of organic surfaces during drying (Birch, 1960; Orchard and Cook, 1983; van Gestel et al., 1991). This response may also vary with soil texture, quality and quantity of soil organic matter, temperature, frequency of drying and wetting cycles, and the amount of added water (Borken et al., 2003). Another explanation for the correlation between $\mathrm{OM}$ and the amount of $\mathrm{P}$ solubilized takes into account the organic matter available for microorganisms. As more organic matter is found in the soil, this may result in the proliferation of microorganisms that take advantage of the available source of nutrients and energy provided by the organic matter. As a result more microorganisms undergo cell lysis 

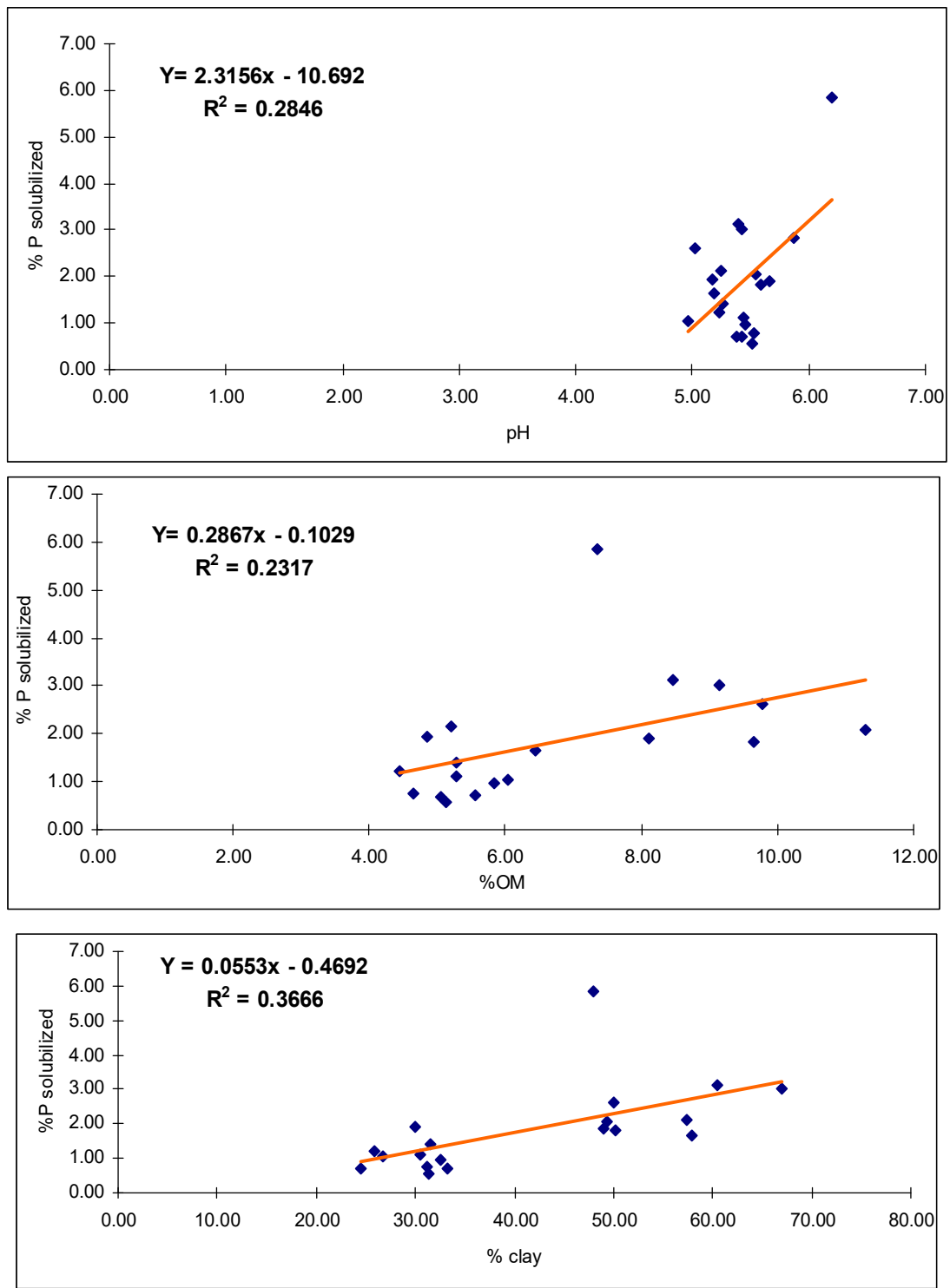

Figure 2. Relationship between the amounts of $\mathrm{P}$ solubilized to $\mathrm{pH}$ and $\mathrm{OM}$, and clay contents of forest and paddy soils studied 
(Turner et al., 2003) which has recently been reported to occur upon rapid rewetting of dried soils and ultimately resulting in more $P$ released from soil with higher $\mathrm{OM}$ content. The significant correlation between soil $\mathrm{pH}$ and $\mathrm{P}$ solubilization reflects the limiting effect of low $\mathrm{pH}$ and the enhancing effect of near neutral $\mathrm{pH}$ on soil microbial activity.

The transformation of one form of phosphate into another is controlled mainly by $\mathrm{pH}$. Soluble calcium bound $\mathrm{P}(\mathrm{Ca}-\mathrm{P})$ which is the active form of $\mathrm{P}$ is converted into less soluble $\mathrm{Al}$ and $\mathrm{Fe}$ phosphates as soils become more acid (Sanchez, 1976).

\section{Nitrogen mineralization}

Total inorganic $\mathrm{N}$ of the forest soil increased significantly from the initial extraction to the $7^{\text {th }}$ day but between the $7^{\text {th }}$ and $14^{\text {th }}$ day the corresponding change in $\mathrm{N}$ concentration was not significant (Figure 3 ). Correlation analysis yielded highly significant relationship between the amount of $\mathrm{N}$ mineralized and OM, total N, amount of clay, and extractable P (Table 2). Since nitrogen mineralization is the sum of $\mathrm{NO}_{3}{ }^{-}$and $\mathrm{NH}_{4}{ }^{+}$concentrations measured after rewetting, the values are dependent upon the concentration of $\mathrm{NO}_{3}{ }^{-}$and $\mathrm{NH}_{4}^{+}$ mineralized. $\mathrm{NH}_{4}^{+}$followed an increasing trend from the initial up to the $14^{\text {th }}$ day of extraction after rewetting while $\mathrm{NO}_{3}{ }^{-}$showed a decreasing trend (Figures 4 and 5).

A similar trend of increasing $\mathrm{NH}_{4}^{+}$and decreasing $\mathrm{NO}_{3}{ }^{-}$concentration was observed by Walker et al. (2003). Their study involved saturating soils obtained from the humus layer of forest soils and subjecting it to incubation in order to study the fate of $\mathrm{N}$ leading to bioavailability or immobilization in forest soils. Their study revealed a decreasing trend in $\mathrm{NO}_{3}^{-}$concentration but an increasing trend in $\mathrm{NH}_{4}^{+}$at the end of the incubation period. One hypothesis they cited regarding $\mathrm{N}$ immobilization is abiotic reduction of $\mathrm{NO}_{3}{ }^{-}$to $\mathrm{NO}_{2}^{-}$ and reaction of $\mathrm{NO}_{2}^{-}$with dissolved $\mathrm{OM}$ to produce dissolved organic nitrogen (DON). They also added that water saturation apparently enhanced denitrification and either stimulated mineralization or inhibited nitrification, thus yielding lower $\mathrm{NO}_{3}^{-}$and higher $\mathrm{NH}_{4}^{+}$than did unsaturated conditions. Immobilization may also be an important retention mechanism for $\mathrm{N}$. Nitrate 


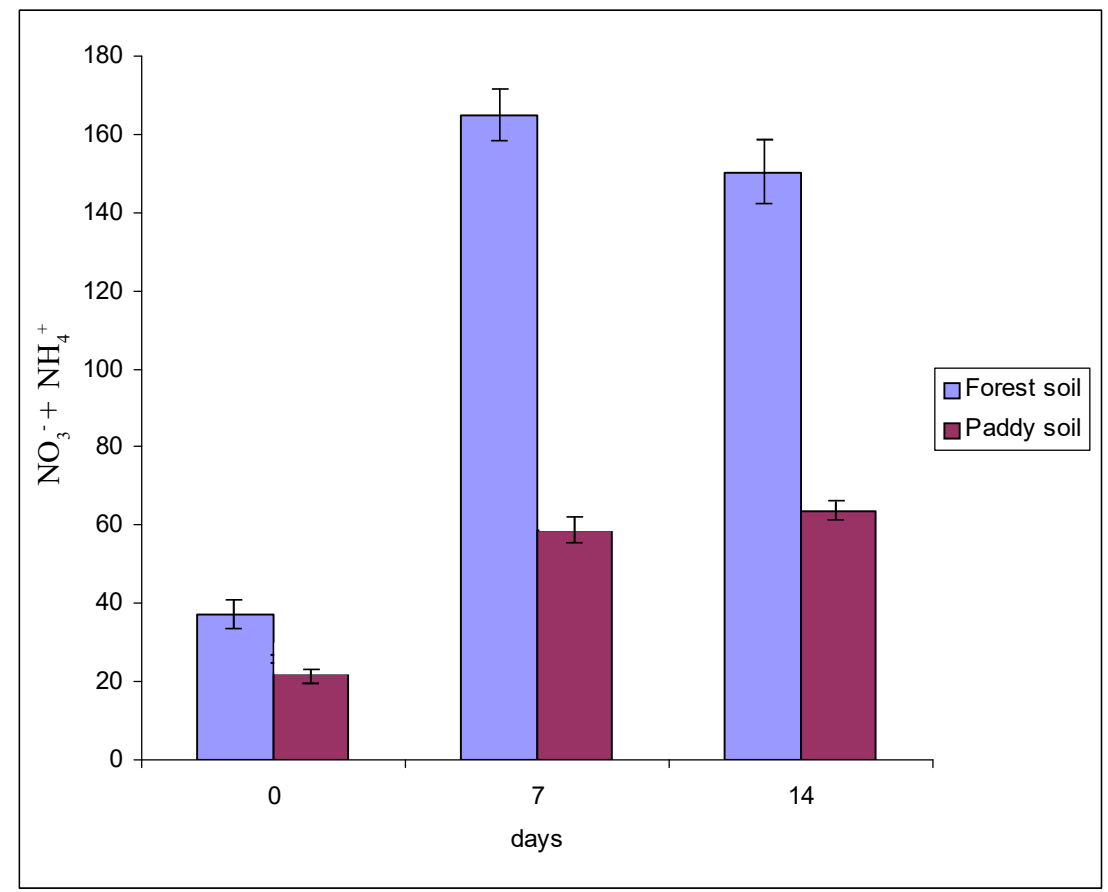

Figure 3. Mean $\mathrm{NO}_{3}^{-}+\mathrm{NH}_{4}^{+}$concentration of the forest and paddy soils at different rewetting times 


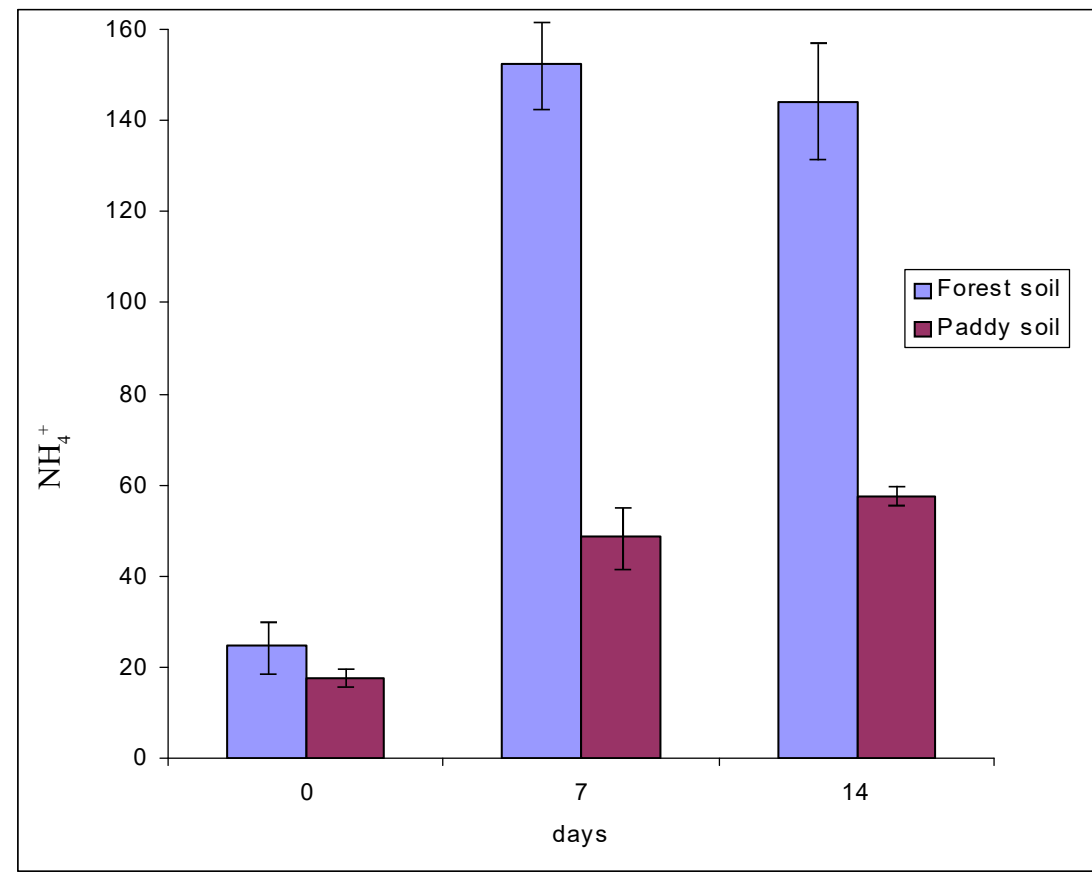

Figure 4. Mean $\mathrm{NH}_{4}^{+}$concentration of forest and paddy soils at different rewetting times 


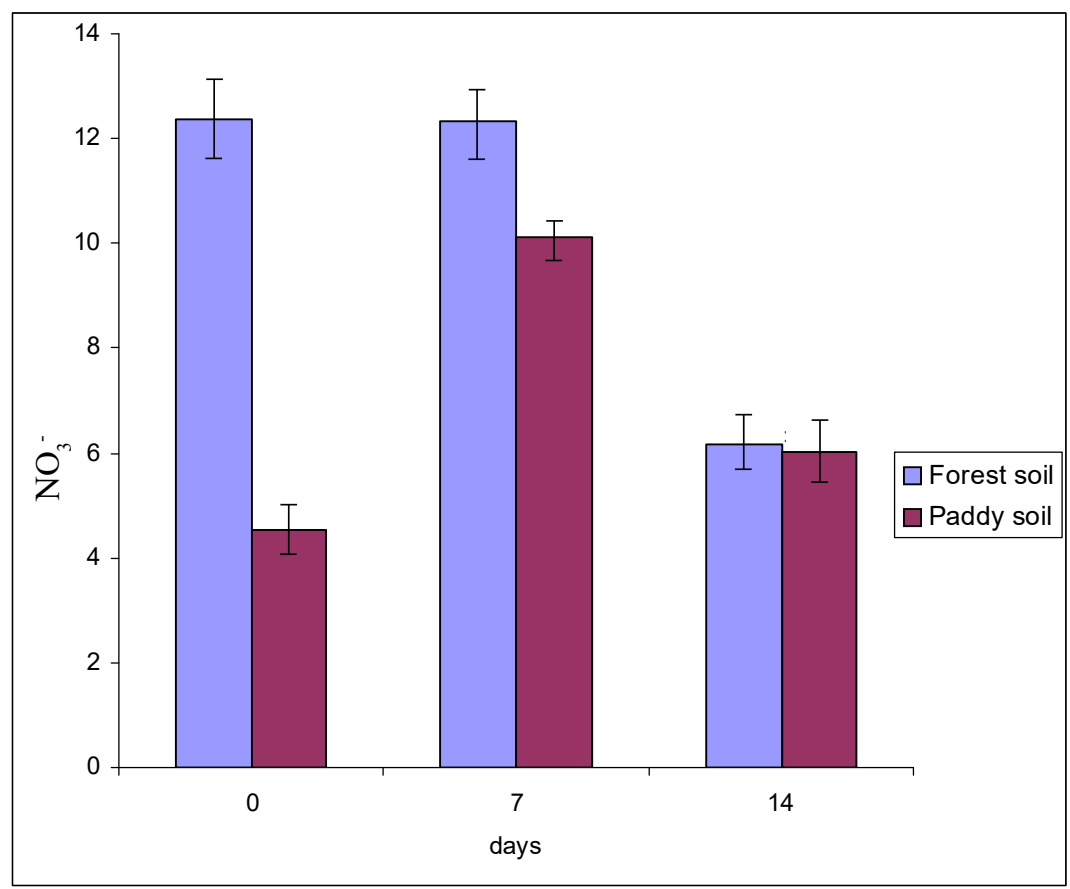

Figure 5. Mean $\mathrm{NO}_{3}{ }^{-}$concentration of forest and paddy soils at different rewetting times 
is readily leached from the biologically active zone of the soil, whereas organic $\mathrm{N}$ is much less mobile (McGroddy et al., 2004). In ecosystems on highly weathered soils, immobilization in the litter layer functions as a nutrient retention mechanism of N (Went and Stark, 1968; Stark and Jordan, 1978).

Another explanation for the decreasing trend of $\mathrm{NO}_{3}{ }^{-}$levels in the forest soil takes account of the probable effect of drying on the microbial communities linked to nitrification. It is possible that the microorganisms are well adapted to the humid conditions of the forest where the soil is moist throughout the day and that drying the soils possibly reduced their population so that even in the presence of enough substrate for nitrification (provided by the increasing $\mathrm{NH}_{4}^{+}$), nitrification is still limited. Haney et al. (2004) also dried and rewetted soils and concluded that soil-nitrifying bacteria were more sensitive to desiccation at higher drying temperatures. Fierer et al. (2003) also observed that frequent drying-rewetting cycles may alter the speciûc composition of microbial communities by selecting for microbes that can survive rapid changes in water potential. Physiological stress, such as that imposed by drying and rewetting, could reduce total soil microbial diversity by favoring a portion of the microbial community best adapted to coping with the given stress (Atlas, 1984; Schimel et al., 1999). Brady and Weil (1999) also mentioned that the nitrifying bacteria are more sensitive to environmental conditions than are the broad groups of heterotrophic organisms responsible for the release of $\mathrm{NH}_{4}{ }^{+}$ions from organic nitrogen compounds.

The decrease in $\mathrm{NO}_{3}^{-}$levels may also be the result of $\mathrm{NO}_{3}^{-}$leaching through the soil prior to extraction with $1 \mathrm{~N} \mathrm{KCl}$. In this study, the soil was equilibrated with distilled water for 24 hours and brought to field capacity by draining for 48 hours prior to the extraction. In a separate experiment, this hypothesis was tested by determining the presence of $\mathrm{NO}_{3}^{-}$on the leachate, which drained through the soil after equilibration when the soil was brought to field capacity. This experiment was conducted initially and after $7^{\text {th }}$ days of drying on nine randomly selected samples of the forest and paddy soils used in the main experiment. The results showed that leachates tested positive for $\mathrm{NO}_{3}{ }^{-}$(Table 3) which confirms that some of the $\mathrm{NO}_{3}{ }^{-}$may have been lost through draining after equilibration. It also showed an average of $44 \%$ increase in $\mathrm{NO}_{3}{ }^{-}$from the initial testing to the $7^{\text {th }}$ day of drying which could signify the increase in the amount of $\mathrm{NO}_{3}{ }^{-}$in the soil after the $7^{\text {th }}$ day of drying. 
Table 3. Percent increase of $\mathrm{NO}_{3}{ }^{-}$concentration of water drained after 24 hours equilibration of forest and paddy soils at initial and 7 days of drying.

\begin{tabular}{lllll}
\hline Soil & \multirow{2}{*}{ Sample } & \multicolumn{2}{c}{$\mathrm{NO}_{3}{ }^{-}(\mathrm{ppm})$} & \%increase \\
\cline { 3 - 5 } & & \multicolumn{2}{c}{ Tnitial } & \\
\hline Forest & & & & \\
& 1 & 1.32 & 1.97 & 49 \\
& 2 & 2.63 & 3.29 & 25 \\
& 3 & 2.63 & 3.29 & 25 \\
& 4 & 2.63 & 3.29 & 25 \\
& 5 & 1.97 & 3.29 & 67 \\
Paddy & & & & \\
& 1 & 2.63 & 3.29 & 25 \\
& 2 & 3.95 & 5.27 & 33 \\
& 3 & 4.61 & 8.56 & 86 \\
& 4 & 3.29 & 4.61 & 40 \\
\multirow{2}{*}{ Average } & & 2.85 & 4.10 & 44 \\
\hline
\end{tabular}

\section{IMPLICATIONS}

The rewetting of soils resulting from the seasonal variation of rainfall and alternate irrigation and drainage of rice paddy soils has the potential to accelerate eutrophication.

Total water-extractable $P$ released during the drying and rewetting experiment, which is the sum of all the water-extractable P released in the drying-rewetting procedure, exceeded the critical concentration range of 10$30 \mathrm{ppb}(\mathrm{NRC}, 1993)$. Although the required concentration of $\mathrm{P}$ in the soil solution for normal plant growth is usually $0.20-0.30 \mathrm{ppm} P$, the solubilization of $\mathrm{P}$ because of drying and rewetting may be a key factor in maintaining forests which usually have low levels of available P. It may also be noted that the forms of $\mathrm{P}$ that are released during solubilization are said to be bioavailable and readily available to plants (Kuo, 1996).

Organic $\mathrm{P}$, which is the dominant form of $\mathrm{P}$ released after rewetting (Turner and Haygarth, 2001), is also less likely to be occluded by geochemical reactions with the soil surface. Although plants have not been shown to directly take up organic $\mathrm{P}$, the organic $\mathrm{P}$ pool may play an important role in plant nutrition (McGill and Cole, 1981; Stevenson and Cole, 1999). Plants and 
microbes both produce extracellular phosphatases that are readily mineralize most common organic $\mathrm{P}$ compounds into labile inorganic phosphates (McGill and Cole, 1981).

Sanchez (1976) stated that organic P normally accounts for $20-50 \%$ of the total topsoil $\mathrm{P}$ and in the more highly weathered Oxisols, Ultisols, and Alfisols it often represents $60-80 \%$ of the total soil $\mathrm{P}$. He added that in nofertilizer agriculture such as in Africa, organic $\mathrm{P}$ is considered as the main source of $\mathrm{P}$ for plants and hence its maintenance is of great practical significance in traditional agricultural systems. The importance of organic $\mathrm{P}$ has been presented by Omotoso (1971), who reported sharp yield increase with $\mathrm{P}$ applications only when the soil organic $P$ content was less than $150 \mathrm{ppm}$ in cacao plantations in Ghana.

Laboratory experiments in Ghana suggested that organic $\mathrm{P}$ may release 2-27 ppm P to the soil according to Acquaye (1963). He also reported that $\mathrm{N}$ and $P$ application increases organic P mineralization. Awan(1964) also reported that increased yields of corn, sorghum, and cowpeas due to liming were associated with increased mineralization of soil organic $P$. These effects can be attributed to the establishment, with fertilization and liming of a more favorable environment for the microorganisms responsible for mineralization.

The sum of $\mathrm{NO}_{3}^{-}$released during rewetting after $7^{\text {th }}$ and $14^{\text {th }}$ days of drying also exceeded the maximum contamination limit of $10 \mathrm{ppm} \mathrm{NO}_{3}^{-}$for both sites. The drainage of paddy soils may thus increase the release of $\mathrm{NO}_{3}^{-}$ from the soil, which is highly mobile because microorganisms responsible for converting ammonium to nitrate are aerobic (Sanchez, 1976).

It should also be noted that $\mathrm{N}$ mineralized is also available for plant uptake and hence may play an important role in supporting native vegetation and agricultural crops. Birch (1960) stated that organic $\mathrm{C}$ and N mineralization are faster under alternate wetting and drying than under conditions with optimum moisture and hence reducing $\mathrm{C}: \mathrm{N}$ ratios. He added that a residue material of $1.5 \% \mathrm{~N}$ was mineralized under alternate wetting and drying but immobilized under constant moisture. Sanchez (1976) noted that this phenomenon is probably associated with a more active microbial population after drying and rewetting the soil or perhaps an increased accessibility of humus to microorganisms by shrink-swell of clay minerals or thin oxide coats.

The results of this study also imply that biogeochemical mechanisms such as drying and rewetting effect on soils play a significant role in releasing nutrients 
from its pools in the soil and those bound in OM. These nutrients are directly available for plant uptake and if transported to bodies of water, they may significantly affect water quality. $P$ fixed in clays may also be released due to the physical stresses induced by soil drying. This may also be true for $\mathrm{NH}_{4}^{+}$ fixed in clays.

Soil properties such as $\mathrm{pH}, \mathrm{OM}$, total $\mathrm{N}$, and clay significantly influence $\mathrm{P}$ solubilization as well as $\mathrm{N}$ mineralization. This is probably due to their effect on soil microbial communities directly involved in $\mathrm{P}$ solubilization and $\mathrm{N}$ mineralization. Soil $\mathrm{pH}$ and amount of clay may also influence $\mathrm{P}$ solubilization as their combined effect may determine the amount of extractable P, which also limits microbial growth. Soils may contribute to $\mathrm{N}$ and $\mathrm{P}$ pollution of ground and surface waters as a result of drying and rewetting process. The abovementioned soil properties influence the growth and function of microbial communities involved in biogeochemical processes or directly responds to physical stresses imposed by rewetting such as exposure of OM surfaces, which make it more available for microbial decomposition and hence consequent release into the soil and soil solution.

\section{CONCLUSION}

Based on the results of the study, it can be concluded that $P$ solubilization and $\mathrm{N}$ mineralization increased after rewetting of forest and paddy soils and that the levels of increase in water-soluble $\mathrm{P}$ and $\mathrm{NO}_{3}{ }^{-}$have the potential to accelerate eutrophication if transported to water bodies. The soil is an important non-point source of phosphate and nitrate pollution of water bodies. Phosphorus solubilization is correlated to $\mathrm{pH}, \mathrm{OM}$, total nitrogen and clay content while $\mathrm{N}$ mineralization is correlated to clay content, OM, total $\mathrm{N}$ and extractable $\mathrm{P}$. The release of $\mathrm{N}$ and $\mathrm{P}$ due to rewetting appears important to nutrient availability for the growing plants.

\section{REFERENCES}

ACQUAYE D.K. 1963. Some significance of soil organic matter on soil organic phosphorus mineralization in phosphorus nutrition of cocoa in Ghana. Plant Soil. 19: 65-80. 
ASIO V.B. 1996. Characteristics, weathering, formation and degradation of soils from volcanic rocks in Leyte, Philippines. Hohenheimer Bodenkundliche Hefte 33, Stuttgart.

ASIO V.B., JAHN R.,STAHR K., and J. MARGRAF. 1998. Soils of the tropical forests of Leyte, Philippines: 2. Impact of different land uses on status of organic matter and nutrient availability. In: Soil of Tropical Forest Ecosystems: Characteristics, Ecology and Management. Schulte, A. and D. Ruhiyat (eds). Springer-Verlag Berlin, Heidelberg, New York. pp. 37-44.

ATLAS R. 1984. Use of microbial diversity measurements to assess environmental stress. In: Current Perspectives in Microbial Ecology. American Society for Microbiology. Klug, M. and C. Reddy (eds) Washington, DC. pp. 540-545

AWAN A.B. 1964. Effect of lime on the availability of phosphorus in Zamorano soils. Soil Sci Soc Am Proc. 28: 672-673.

BIRCH H.F. 1960. Nitriûcation in soils after different periods of dryness. Plant and Soil 12: 81-96.

BORKEN W., DAVIDSON E.A., SAVAGE K., GAUDINSKI J., and S.E. TRUMBORE. 2003. Drying and wetting effects on carbon dioxide release from organic horizons. Soil Sci. Soc. Am. J. 67: 1888-1896.

BRADY N.C. and R.R. WEIL. 1999. The Nature and Properties of Soils. 12th ed. Prentice Hall. Upper Saddle River, NJ.

BREMNER J.M. and C.S. MULVANEY. 1982. Nitrogen- Total. In: Methods of Soil Analysis Part 2. Chemical and Microbiological Properties 2nd Edition. Page et. al (eds) Soil Sci. Soc. Amer. and Amer. Soc. Agron., Madison, Wisconsin. pp. 595-622.

BREMNER J.M. 1965. Inorganic forms of nitrogen. In: Methods of Soil Analysis Part 2. Chemical and Microbiological Properties 2nd Edition. Black et. al (eds). Soil Sci. Soc. Amer. and Amer. Soc. Agron., Madison, Wisconsin. pp. 1179-1232.

DICK W.A., and M.A. TABATABAI. 1977. An alkaline oxidation method for determination of total phosphorus in soils. Soil Sci. Soc. Am. J. 41:511-514.

FIERER N., SCHIMEL, J.P., and P.A. HOLDEN. 2003. Influence of drying-rewetting frequency on soil bacterial community structure. Microb. Ecol . 45: 63-71 SpringerVerlag New York Inc.

GUPPY C.N., MENZIES N.W., MOODY P.W., and F.P.C. BLAMEY. 2005. Competitive sorption reactions between phosphorus and organic matter in soil: a review. Aust. J. Soil Res. 43: 180-201.

HANEY R.L., FRANZLUEBBERS A.J., PORTER E.B., HONS F.M. and D.A. ZUBERER. 2004. Soil carbon and nitrogen mineralization: Influence of drying temperature. Soil Sci. Soc. Am. J. 68: 489-492. 
HOUGHTON J.T., JENKINS G.J., and J.J. EPHRAUMS. 1992. Climate Change. The IPCC Scientific Assessment. Cambridge University Press. 212 pp.

HUBBARD BROOK RESEARCH FOUNDATION. 2003. Nitrogen pollution. Science Links Publication, Vol. 1, No. 2, 25pp.

ISRIC. 1995. Procedure for Soil Analysis (L.P. van Reeuwijk, Ed). Wageningen, The Netherlands.

IUSS WORKING GROUP WRB. 2006. World Reference Base for Soil Resources (2 ${ }^{\text {nd }} \mathrm{ed}$.). World Soil Resources Report No. 103, FAO, Rome.

JORDAN C.F. 1985. Nutrient Cycling in Tropical Forest Ecosystems. John Wiley and Sons. New York. 189 pp.

KUO S. 1996. Phosphorus. In: Methods of Soil Analysis: Chemical Methods. Part 3; Sparks, D.L., ed.; WASA and SSSA: Madison, WI, 869-919.

LANDON J.R. (ed.) 1991. Booker Tropical Soil Manual. Longman Scientific and Technical, England, 474 pp.

LONGMAN K.A. and J. JENIK. 1987. Tropical Forests and its Environment. (2nd edn.) Longman Scientific and Technical, Essex. 347 pp.

LUCAS R. and D. WARNCKE. 1997. Managing organic soils to reduce non-point pollution. Michigan State University Extension. Ext. Bulletin WQ 03.

MCGILL W.B. and C.V. COLE. 1981. Comparative aspects of cycling of organic C, N, S and $\mathrm{P}$ through soil organic matter. Geoderma 26: 276-86.

MCGRODDY M.E., SILVER W.L., and R.C. DE OLIVEIRA, JR. 2004. The effect of phosphorus availability on decomposition dynamics in a seasonal lowland Amazonian forest. Ecosystems 7: 172-179.

MURPHY J. and J.C. RILEY. 1962. A modified single solution for the determination of phosphate in natural waters. Anal. Chem. Acta. 27: 31-36.

NAVARRETE I.A., K. TSUTSUKI, V.B. ASIO, and K. RENZO. 2009. Characteristics and formation of rain forest soils derived from late Quaternary basaltic rocks in Leyte, Philippines. Environ. Geol. 58: 1257-1268.

NATIONAL RESEARCH COUNCIL. 1993. Soil and Water Quality: An Agenda for Agriculture. National Academy Press, Washington, D.C. 516 pp.

NELSON D.W. and L.E. SOMMERS. 1982. Total Carbon, Organic Carbon and Organic Matter. In: Methods of Soil Analysis (Page et. al, eds) Part 2. Chemical and Microbiological Properties 2nd Edition. Soil Sci. Soc. Amer. and Amer. Soc. Agron., Madison, Wisconsin. pp. 539- 577. 
NRC 1995. Wetlands:Characteristics and Boundaries. National Academy Press, Washington, DC. 308 pp.

OLSEN S.R. and L.E. SOMMERS. 1982. Phosphorus. In: Methods of Soil Analysis (Page et. al, eds) Part 2. Chemical and Microbiological Properties 2nd Edition. Soil Sci. Soc. Amer. and Amer. Soc. Agron., Madison, Wisconsin. pp. 403- 427.

OMOTOSO T.I. 1971. Organic phosphorus contents of some cocoa growing soils of Southern Nigeria. Soil Sci. 112: 195-199.

ORCHARD V.A., and F.J. COOK. 1983. Relationship between soil respiration and soil moisture. Soil Biol. Biochem. 15: 447-453.

ROSEN C.J. and B.P. HORGAN. 2006. Preventing pollution problems from lawn and garden fertilizers. Regents of the University of Minnesota.

SANCHEZ.P.A. 1976. Properties and Management of Soils in the Tropics. John Wiley and Sons. New York.618 pp.

SCHIMEL J.P., J.M. GULLEDGE J.S. CLEIN-CURLEY J.E. LINDSTROM, and J.F. BRADDOCK. 1999. Moisture effects on microbial activity and community structure in decomposing birch litter in the Alaskan taiga. Soil Biol. Biochem. 31: 831-838.

SCHINDLER D.W. 1977. Evolution of phosphorus in lakes. Science (Washington, DC) 195: 260-262.

SIMONSSON M., D. BERGGREN, and J.P. GUSTAFSSON. 1999. Solubility of aluminum and silica in spodic horizons as affected by drying and freezing. Soil Sci. Soc. Am. J. 63: 1116-1123.

SOIL SURVEY STAFF. 2006. Keys to Soil Taxonomy. $10^{\text {th }}$ ed. USDA-National Resources Conservation Service, National Soil Survey Center, Lincoln, NI.

STARK N.M. and C.F. JORDAN. 1978. Nutrient retention by the root mat of an Amazonian rain forest. Ecology 59: 434-437.

STEVENSON F.J., and M.A. COLE.1999. The phosphorus cycle. In: Cycles in Soil: Carbon, Nitrogen, Phosphorus, Micronutrients. New York: Wiley. p 279-329.

TAN KH. 1993. Principles of soil chemsitry. Marcel Dekker, New York.

TURNER B.L., J.P. DRIESSEN, P.M. HAYGARTH, and I.D. MCKELVIE.2003. Potential contribution of lysed bacterial cells to phosphorus solubilization in two rewetted Australian pasture soils. Soil Biol. Biochem. 35: 187-189.

TURNER B.L., and P.M. HAYGARTH. 2001. Phosphorus solubilization in rewetted soils. Nature (London) 411: 258. 
VAN GESTEL M., J.N. LADD and M. AMATO. 1991. Carbon and nitrogen mineralization from two soils of contrasting texture and microaggregate stability: Influence of sequential fumigation, drying and storage. Soil Biol. Biochem. 23: 313-322.

WALKER C., E. DAVIDSON, W. KINGERLEE, and K. SAVAGE. 2003. Incubation conditions of forest soil yielding maximum dissolved organic nitrogen concentrations and minimal residual nitrate. The Biological Bull. 205: 256-257.

WENT F.W. and N. STARKE. 1968. Mycorrhiza. Bioscience 18: 1035-1039.

ZIKELI S., V.B. ASIO and R. JAHN. 2000. Nutrient status of soils in the rain forest of Mt. Pangasugan,Leyte, Philippines. Ann. Trop. Res. 22(1\&2): 78-88. 